\title{
The Implementation of Effective Management of School in MI Darusssalam
}

\author{
Diniyah Maftuchah ${ }^{1}$, \\ Nur Efendi ${ }^{2}$ \\ Master of Islamic Education Management, Universitas Muhammadiyah Sidoarjo, Indonesia \\ 1diniyahmaftuchah11@gmail, \\ ${ }^{2}$ nurefendi17@ymail.com
}

\begin{abstract}
The leading madrasah formulation or effective madrasah in darussalam mi is not exclusive from the effective management management implementation. In this research is some of the problems that can be taken (1) how does the implementation of effective madrasah management management in the "darussalam" mi? ; (2) how is the implementation of effective madrasah activities in mi "darussalam" sugihwaras candi sidoarjo? ; the main instruments in this research are own research and help instruments including observation guidelines, interview guidelines, interview guidelines and documentation guidelines. On the data collection techniques used are observation techniques, interview techniques and documentation techniques. This research uses a qualitative descriptive research design. This research results shows in effective school management management implementation in "darussalam" mi all are not exposed from madrasah vision and mission and madrasah management management is mentioned in madrasah work plan. In addition, the forms and programs made by madrasah implemented in the development of activities associated with student learning in this thing including school culture or madrasah.
\end{abstract}

Keywords: Implementation, Effective Management, School or Madrasah Effetive.

\section{INTRODUCTION}

Basically Madrasas are not unlike an institution or institution. As an institution or institution, Madrasas carry out a specific mission, namely to carry out the educational process, the process of socialization, and the transformation process of students in order to deliver them to be ready to attend education at the next level that is better. The formulation of superior Madrasas or effective Madrasas is certainly our dream. To go in that direction requires the right strategy. In addition, it refers to 8 education standards made by the National Education Standards Agency (BSNP) which include (1) Graduates Competency Standards, (2) Content Standards, (3) Process Standards, (4) Education Standards and Education Personnel, (5 ) Facilities and Infrastructure Standards, (6) Management Standards, (7) Education Financing Standards, (8) Educational Assessment Standards.

Effective management of madrasah management is the management of madrasas that have the ability to empower every important Madrasah component, both internally and externally, and have a good, transparent and accountable management system in order to achieve the Madrasah vision and mission effectively and efficiently. ThereforeIn this study there are 2 data consisting of primary data and secondary data.

a. Primary Data is a source of research data obtained directly from the original source in the form of interviews, polls from individuals or groups (people) or observations of an object, event or test results (objects), madrasas can be said to be effective if Islamic religious education institutions have goals, missions and goals, so as to produce reliable outputs.

According to Fatah Syukur explained in his book Management Education in Madrasas that there are several general principles that must be considered in building a madrasa (a) Increasing philosophical understanding and acceptance, the values and mission of the madrasa, (b) Attention to the achievement of goals and objectives, (c ) Effective leadership, (d) Strategic multi-dimensional development plans and implementation, (e) School management and community participation, (f) Responsibilities clearly delegated topeople involved or influenced by madrasah activities, (g) Participation in decision making, (h). Determination of high standards, (i) Students active learning, (j) Environment of teaching and learning motivation, (k) Effectiveness of the team of teachers and principals, (1) System that is honest in evaluation and accountability [1].

Management of management Effective development of madrasas is determined by the success rate of all factors how to empower and manage existing educational resources independently and creatively by involving Madrasahs and the community in making participatory decisions in order to improve the quality of their Madrasah education. In addition, the development of effective Madrasahs will certainly not be separated from the 
management system carried out by Madrasah heads. Madrasas can develop if a leader can run well-made programs. As described in the word

Allah QS. Ar-Ra'ad verse 11

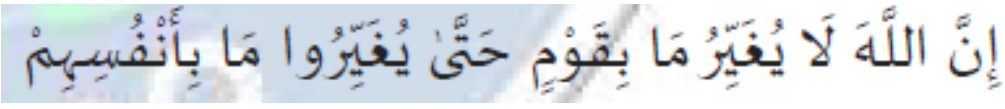
themselves.

Meaning: Verily God does not change the state of a people so that they change the conditions that exist in

From here in implementing effective madrasah management, the Madrasah head must involve several Madrasah paradigms, namely teachers, students, employees, parents and the community who support the management of the madrasah. The success or failure of a Madrasah program depends on the way the Madrasah head runs programs that have been made previously written in the Madrasah Work Plan (RKM)

The implementation of effective management of Madrasah management can be reflected in the profile of Madrasahs that have regularity in various aspects to achieve their goals. These aspects include students, teachers and other education personnel, curriculum, infrastructure, teaching and learning activities, extracurricular activities, guidance and counseling, Madrasah partnerships with the community to special activities that develop on Madrasah needs and inspiration. The point is that there is a synergy to achieve the targets that have been set. As an educational institution that has Islamic characteristics, madrassas play an important role in the process of forming students' personalities, because through this madrasa education parents hope their children have two abilities at once, not only general knowledge (science and technology) but also have personality and commitment who are high in religion (IMTAQ).

\section{MAIN PART}

In this study using qualitative research methods using the approach used is a phenomenological approach. Phenomenalogical approach seeks to express and learn and understand a phenomenon and its unique and unique context experienced by individuals to the level of the individual's beliefs. In psychology, the phenomenology model is intended to get clarity of a phenomenon that occurs in natural situations experienced by individuals every day [2].

This study aims to describe objectively the implementation of effective management of madrasah in MI Darussalam Sugihwaras Candi Sidoarjo. In accordance with these objectives this research uses a qualitative descriptive approach. The purpose of qualitative research is to describe, express, and explain systematically, factually and accurately about the facts, traits and inter-phenomenon relationships that are examined [3]. b. Secondary data is a source of research data obtained through intermediary media orindirectly in the form of books, records, existing evidence, or archives both published and not publicly published.

Data collection techniques in this study are using the triangulation method which isobtained from research instruments which include: Observation, Interview, Questionnaire,Documentation. Data analysis is one of a very important series of research activities. Through this analysis, the data or information collected becomes more meaningful. There are several steps taken in analyzing the data as follows: (1) Researchers collect and check (re-examine) data obtained from field notes (observation, interviews, and documentation), (2) Researchers reduce data obtained from records field, by selecting and sorting out relevant data and not relevant to the research objectives. Relevant data will be analyzed, while less relevant data will be set aside (not released), (3) After the data has been reduced, the next step is data presentation which includes: (a) identification, (b) classification, (c) preparation, (d ) explanation of the data in a systematic, objective, and comprehensive manner, and (e) meaning, (4) Conclusion, the researcher concludes the results of the study by adjusting the results of his research with existing theories.

\section{DATA ANALYSES AND RESULTS}

Based on the results of the interview with Mr. Ary Irawanto as the head of the madrasah, the condition of the madrasa is now different from before.

"The condition of Madrasah Darussalam before it became as it is now is running like a school around but without programs that stand out and many in some ineffective management. Since the reformation of the head of the madrasah, the revormation is a request from all the management of the Darussalam foundation. "

Effective madrasas are certainly madrasas that have an effective management system. In line with Danim, the criteria for effective Madrasahs are to encourage activity, multicultural understanding, gender equality, and develop appropriately learning according to the standards of potential possessed by students, expecting students to take on the role of responsibility in learning and their behavior, determining the feedback meaningful to students, for example for each discipline that applies in Madrasas given points for students who violate and are given rewards or rewards for the best students in behaving so that there is feedback from student 
behavior, creating a sense of security, mutual respect which is a habit positive habits so that it can become a culture in every Madrasah, actively involving families in helping students [4].

In addition, from the results of interviews with madrasah heads, efforts were made in developing this effective madrasah which stated that

"Improving the performance of both school principals, educators, and employees, such as for example to improve the performance of principals we can utilize the Madrassah Head Working Group (K3M) while for improving the Professionalism of our Teachers we usually include educators in training.or existing seminars. In addition, we also improve the completeness of madrasa infrastructure so that teaching and learning activities can run smoothly. We also usually provide guidance to students with a structured and planned program such as the addition of lessons for students in schools who need more guidance. The development carried out is:

1. Improve discipline both for Teachers, employees or students

2. Make program activities in a structured and directed manner

3. Encourage all students to excel and reward students who excel

4. Perform control or supervision, supervision, and make time to plan together with teachers and allow feedback for the success of madrasas

5. There is transparency in all school activities both in terms of financing, activity programs and matters relating to students.

Disisi lain, ada beberapa aspek-aspek yang menjadi sentral dalam mengembangkan madrasah Darussalam diantaranya:

a. Penguatan kepemimpinan kepala sekolah

b. Peningkatan profesionalitas tenaga pendidik dan karyawan

c. Adanya transparansi pengelolaan

d. Target prestasi yang tinggi

As with research conducted by Weber, $G$ which states that Madrasas that are effective in urban areas in the United States, especially in New York City, Kansas City, and Los Angels, find that the four determinants of Madrasah effectiveness are as follows:

1. Strong leadership

2. High expectations for student academic achievement

3. Madrasah climate that is conducive, calm, and suitable for learning.

4. Emphasis on reading skills [5].

On the other hand, the results obtained from this study in the development of madrasas are effective in line with Beck and Murpuly which suggests four things that are binding for effective schools which include:

a. Follow school to develop learning specifically, but not exclusively for students.

b. Bind individuals to carry out leadership tasks and centrally focus energy and resources from stakeholders.

c. Binding to maintain a communal atmosphere in schools and unite schools with society more broadly and mutually beneficial.

d. Binding to support efforts to build the capacity of administrative staff, teachers, and parents so that they can better support student learning.

Based on the results of the interview with Mr. Ary Irawanto as the head of the madrasah stated that"

"There are so many programs conducted by Madrasah Daraussalam to expand madrasas especially those related to student learning activities. I formulated school programs by deliberation or sitting together with all teachers to make a measurable and realistic program in accordance with the dynamics of the regulation and the demands of the times. I also always pay attention to the input from all parties for the implementation of effective programs for all students. "

Basically, the implementation of effective forms of madrasah activities in Sugihwaras Darussalam Candi Sidoarjo is very influential on effective school development. The process of developing school organizational effectiveness according to Kennedy through various stages in the main steps of school effectiveness development process, namely (1) school community orientation in the process, (2) condition school self-evaluation with instrument tools, (3) identify, conclude and analyze data, (4) identification of school priority development needs, (5) preparing school development program plans, (6) implementation of school development program plans and monitoring of progress, (7) evaluation of schooldevelopment plans, (8) communication of the impact of school development programs on the community, $(9$ ) subsequent plans and actions of self-evaluation and school development, (10) further evaluation returns to the original process with school orientation in the process [6].

In addition, from these programs there are activities that implement the effectiveness of the development of madrasah Darussalam, among others

1. Promote an increase in the culture of religious obedience with a number of religious activities such as prayers, holidays, and other religious activities that are very useful for students to increase religious obedience. 
2. Planning school programs together

3. Making disciplinary rules for all school residents in a clear and firm manner

4. Implement innovative and creative learning strategies.

As an organization, a school must show a special characteristic in accordance with the vision and mission that has been made by the school and show with a lesson both for the teacher and for the students. This is in line with what was formulated by Philips which stated that the existence of school culture contained a belief, attitude and behavior that characterized the school. From these values the existence of values, beliefs, attitudes and behavior are essential cultural components that can shape the character of madrasah [7].

On the other hand, in the implementation of the forms of programs in this madrasa there are programs that characterize the school culture which includes morning and literacy activities. School culture must also be realized by all constituents as basic assumptions and beliefs that can make the madrasah have an image that boasts stakeholders. Therefore, all individuals have the same position to raise the image through performance that refers to an effective madrasa culture.

The existence of this culture of capability that is in accordance with the demands of learning which can motivate to develop and give positive impact to students in accordance with humanitarian principles. This is in line with the opinions of Deal, Brophy, Grossnickle, Lodkowski, and Jaynes who stated that the atmosphere or environment that fosters motivation to learn can be cultivated at home, in the classroom, or at a wider level, throughout the school. The existence of school culture carried out and implemented in Madrasah Darussalam aims to show more quality to the community. Thus, the forms and programs that have been created by madrasas must reflect positive values, especially in the life and habits of these madrasa students. The implementation of the culture and form of the madrasa program depends on the management pattern of the madrasa coconut system that works with the madrasa elements which in this case the teacher also participates in implementing the culture.

On the other hand, the culture in Madrasah Darussalam that is used is the Morning Prayer culture and literacy culture. The habituation activity $96 \%$ goes according to the expectations of school residents. The Morning Prayer program is carried out to increase students' understanding in learning the Qur'an. According to what Dr. Qurai Syihab which states that every presentation of educational material must be able to touch the soul and mind of students, so that they can realize ethical values or purity which is the basic value of all human activities. This makes it imperative because it is an educational goal of the concept of al quran [8].

\section{CONCLUTION}

a. Management of effective madrasah management at MI "Darussalam" Sugihwaras Candi Sidoarjo Effective madrasas are certainly madrasas that have an effective management system. Management of effective madrasah management at MI "Darussalam" Sugihwaras Candi Sidoarjo, head of the madrasa in making and developing the madrasah Darussalam is inseparable from the making of the madrasa vision and mission.

b. Implementation of effective forms of madrasa activities in the Darussalam Darussalam Sugihwaras Temple Sidoarjo

The existence of forms of activities carried out by the Darussalam madrasah is included in the scope of school culture. Culture in Darussalam has a culture that is specifically characterized by the form of habits and activities carried out by students.

Madrasa culture in Darussalam must have the capability that is in accordance with the demands of learning which can motivate to develop and have a positive impact on students in accordance with humanitarian principles.

\section{REFERENCES}

1. M. A. Drs. Fatah Syukur, NC., Management of Education Based on Madrasah. Semarang: al-Qalam Press, 2006.

2. M. D. dan F. A.-M. Ghany, Kualitati Research Methodolog.. Jogja: ArRuzz, 2012.

3. M. Ainin, Arabic Language Research Methodology. Surabaya: Hilal Pustaka, 2010.

4. S. Danim, New Vision of Madrasah Management. Bumi Aksara, 2007.

5. G. Weber, Innercity Children can be taught to read: four successful schools. Washintong, D.C: Council for Basic Educatioan.

6. M. B. Kennedy, Developing School Effectiveness: A Handbook for Improvement of Junior Secondary Schools (SLTP) Ministry of National Education Directorate of Junior. Jakarta, 2002.

7. "ibid."

8. Q. Shihab, Ground the Quran. Jakarta: Mizan, 1996. 